ISSN: 2224-0616

Int. J . Agril. Res. Innov. \& Tech. 3 (2): 12-15, December, 2013 Available online at http:// www.ijarit.webs.com

\title{
CONTENT ANALYSIS OF AGRICULTURAL TRAINING ADVERTISEMENTS IN NIGERIAN NEWSPAPERS
}

\author{
A. Oloruntoba ${ }^{*}$, J.O. Oladeji ${ }^{2}$ and E.F. Odedele ${ }^{3}$ \\ Received 9 August 2013, Revised 2 December 2013, Accepted 25 December 2013, Published online 31 December 2013
}

\begin{abstract}
It is obvious that the use of newspapers is one of the ways through which literate farmers could access agriculture-related information and are acquainted with innovations in agriculture. This study investigated the content of agricultural training advertisements in three Nigerian newspapers: The Guardian, Nigerian Tribune and Daily Times. Using multistage sampling techniques, 240 editions of these newspapers containing 609 advertisements for five years (2001-2005) were selected. In terms of agricultural subsectoral coverage, $30.3 \%$ were on veterinary services while forestry services recorded the least advertisement (4.0\%). The Nigerian Tribune newspaper has the highest coverage of agricultural training advertisements $40.7 \%$ compared to the $34.7 \%$ and $12.2 \%$ for Daily Times and Guardian newspapers, respectively. The result also showed that majority of agricultural training advertisements (81.10\%) were placed on the non-prominent pages of the selected newspapers. Chi-Square analysis of association between the categories of agricultural training advertisements in the focal newspapers showed that there is significant relationship in the rate at which the sampled newspapers advertise different category of agricultural training advertisements in the newspapers $(p<0.05)$. Chi square analysis also indicated that there is significant association between the placements of agricultural training advertisements and type of newspapers $(\mathrm{p}<0.05)$. This implies that advertisement placement on prominent pages of newspapers is determined by the policy of print media organization which also varies with cost of advertisement. It is therefore recommended that agricultural news items should be given more prominence as a panacea for increased information source to new entrants, especially the literate farmers to encourage farming.
\end{abstract}

Keywords: Agricultural Training Advertisement, Nigerian Newspapers, Literate Farmers

${ }^{1}$ Department of Agricultural Extension, Rural Development \& Gender Studies, University for Development Studies, Tamale, Ghana

${ }^{2}$ Department of Agricultural Extension and Rural Development, University of Ibadan, Ibadan, Nigeria

${ }^{3}$ Department of Agricultural Extension and Rural Development, University of Agriculture, Abeokuta, Nigeria

*Corresponding author's email: yomitoba@hotmail.com (A. Oloruntoba)

\section{Introduction}

Dissemination of different agricultural information are priorities for technological transfer and acquisition of new skills in agriculture especially now that literate but less technically sound individuals are engaging in agriculture. Oladeji (1999) posited that the movements of the new entrant (literate farmers) who usually have higher education than the traditional farmers, into the farming enterprise have brought about an upswing in the literacy level of the farming audience. This group of people, mostly urban based, may rely on the news media especially the print media for the much needed agricultural information. Reilly and Clark (1990) indicate that training is a process through which knowledge, skill and attitude for a purpose of a specific job, task or vocation is developed through instruction and practice. Newspapers serve as the major advertising medium for the smallest retailers as well as some of the largest corporations. Therefore, there are agricultural content in Nigerian daily news; contents that must be content analyzed for efficiency. Content analysis according to Oladeji and Fawole (1999) is a systematic way of reporting social and economic life that is dominated or influenced by casual observations about the content of communication.

A broad channel of communication in extension is the mass media. Most mass media have a wide coverage and a far-reaching effect on agricultural information dissemination. Communication is a vital link in agricultural and rural development. However, agricultural news items have suffered limited coverage in Nigerian Newspaper (Olowu 1990; Salawu, 1983. While advertisements are predominant in most Nigerian dailies, most of the advertisements are non-agricultural (Oladeji and Olowr, 2001). Studies have been undertaken on content analysis of advertisements in 
Guardian newspaper (Oloruntoba and Olowu, 2001) on agricultural news and stories, visuals and information clues in agricultural advertisements (Oladeji, 1999) but none has focused on agricultural training advertisements in Nigerian newspapers. It is against this background that this study will provide answers to the following questions:

- What are the content categories of agricultural training advertised in the selected Nigerian newspapers?

- What is the nature of placement of agricultural training advertisements on pages of newspapers?

\section{Methodology}

There are 28 daily newspapers in Nigeria (Media World, 1996) and these newspapers constitute the study population. Sampling of newspapers was based on purposive selection and stratification based on circulation figures, location of publishing house and ownership. A five year period (July 1st 2001 to June 30th 2005) was chosen to determine the coverage given to agricultural training advertisement in three Nigerian newspapers. The period was chosen because it marked the emergence of many agricultural programmes and most especially poverty reduction programmes like Fadama II, Local Empowerment and Environmental Management Programme (LEEMP), Special Programme on Food Security (SPFS) and Community Based Poverty Reduction Project (CPRP) in the nation. Newspapers that were in circulation throughout the five year period of study were purposively considered for sampling. Consequently, The Guardian, Nigeria Tribune and Daily Times Newspapers that have wide coverage both in space and in content were selected.

Using simple random sampling technique in selecting the months in order to determine the number of editions to be examined, $50 \%$ of the months in the five year period were selected for a total of 30 months ( $6 \times 5), 50 \%$ of the weeks in the months were selected for a total of 60 weeks ( $30 \mathrm{x}$ 2 ), while three days were chosen from Monday to Friday as week days and a day from Saturday and Sunday, that is, weekends. This exercise made a total of two hundred and forty days (60 x 4) for the study. Hence, a total of 240 editions of newspapers were selected, used and data were analyzed with both descriptive and inferential statistics. The content of all agricultural training advertisements were analyzed based on their themes. The specific content areas prominently reported are those that have immediate functional relevance for the target audience. However, to facilitate the content analysis, six content categories that were mutually exhaustive and exclusive were developed based on the training category as follows:

- Veterinary Services (VS) training category: This includes training advertisement on livestock related studies: Veterinary nursing and livestock management, veterinary physiology.

- Agricultural Services (AS) training category. This includes training advertisements on fish farming, animal feeds and nutrition, livestock production, pig husbandry, poultry keeping, crop protection, crop production, commercial horticulture, glass house and protected cropping, nursery practice, fruit production, vegetable, flower production, agricultural, food marketing, farm business administration and management, landscape.

- Forestry Services (FS) training category. This includes training adverts on Wood Science, Agro-forestry and forestry related activities.

- Agricultural Technology (AT) training category. This includes training adverts on agricultural mechanization, meat technology, food processing machine and any other agricultural related machine.

- Food Related (FR) training category. This include training advertisements on meat inspection, food and drink inspection, food marketing, food sciences and fisheries.

- Other Agricultural Related Training (OAR) training category. This includes training advertisements on other aspects of agriculture not mentioned.

Position of advertisement in selected newspapers and frequency are the two variables of prominence used in analyzing the editions. All agricultural training advertisements contained in the front page, middle page, back page or centre/special page of the sampled newspaper editions were considered prominent while those on other pages were rated as not prominent. The number of times agricultural training advertisements appears in front and back pages were counted and recorded. Hence, frequency is the number of times agricultural training advertisements appear on the prominent pages of the newspapers.

\section{Reliability of Coding}

To ensure reliability of data, code and re-code method of reliability was employed to crosscheck accuracy of coding using the Spearman Rank Correlation (r). Here 20 newspaper editions out of the total sample were selected. The proportion of agreement was 87 per cent. 


\section{Results and Discussion}

\section{Content category of agricultural training} advertisement

Findings showed that all the categories of Agricultural Training Advertisements were contained in the selected newspapers, except in the Guardian Newspaper that does not contain Veterinary Services and Agricultural Technology Advertisements. Olowu (1990) posited that virtually all aspects of agriculture production activities are newsworthy because they are found in newspapers. Table 1 presents the distribution of the categories of agricultural training advertisements. Findings further revealed that the Nigerian Tribune has relatively the highest coverage with $40.7 \%$ compared with the $34.7 \%$ and $12.2 \%$ for Daily Times and The Guardian respectively.

Table 1. Categories of agricultural training advertisements

\begin{tabular}{lcccccccc}
\hline Advertisement Category & \multicolumn{2}{c}{ Daily } & \multicolumn{2}{c}{$\begin{array}{c}\text { The } \\
\text { Times }\end{array}$} & \multicolumn{2}{c}{$\begin{array}{c}\text { Guardigerian } \\
\text { Tribune }\end{array}$} & \multicolumn{2}{c}{ Overall } \\
& Freq & $\%$ & Freq & $\%$ & Freq & $\%$ & Freq & $\%$ \\
& 32 & 39.0 & 0 & 00 & 29 & 27.6 & 61 & 30.3 \\
Veterinary Services (VS) & 12 & 14.6 & 6 & 42.9 & 15 & 14.3 & 33 & 16.4 \\
Agricultural Services (AS) & 4 & 4.9 & 1 & 7.1 & 3 & 2.9 & 8 & 4.0 \\
Forestry Services (FS) & 10 & 12.2 & 0 & 0.0 & 25 & 23.8 & 35 & 17.4 \\
Agricultural Tech. (AT) & 15 & 18.3 & 3 & 21.4 & 15 & 14.3 & 33 & 16.4 \\
Food Related (FR) & 9 & 11.0 & 4 & 28.6 & 18 & 17.1 & 31 & 15.4 \\
Other Agriculture Related (OAR) & 82 & 100 & 14 & 100 & 105 & 100 & 201 & 100 \\
Sub Total & 154 & 100 & 101 & 100 & 153 & 100 & 408 & 100 \\
Non-Agricultural Advertisements (NAA) & & & & & & & &
\end{tabular}

The dominance of almost a third (30.0\%) of the Veterinary Advertisements training categories may not be unconnected to the outbreak of epidemics such as the avian Influenza (Bird flu), Swine Fever and Swine flu in the livestock subsector within the period in the country. Again, livestock and fish farming are now in vogue among new entrant farmers than other aspects of agriculture. This brings to the fore the specific training needs advertisements for this category of farmers for optimum service delivery. According to FAO (1997), training is useful only when it is designed to meet the need of trainee, and is offered to people who will benefit from it.

Placement of agricultural training advertisements
Findings on Table 2 showed that the majority of agricultural training advertisements were placed on the non-prominent pages of the selected newspapers $(81.10 \%)$ while few $(18.90 \%)$ were displayed on prominent pages. This report is in agreement with previous findings that agricultural news or activities are mostly placed on non prominent newspaper pages (Agumagu, 1988; Fawole, 1995). Placement of agricultural advertisements on prominent pages of newspapers is a function of request for the pages by manufacturers, marketers or advertising agencies of agricultural products or services as well as the ability to pay the advertisement rates of prominent pages as advertisement rates differ for prominent and non-prominent pages of Nigerian Newspapers (Oladeji, 1999; Oloruntoba and Olowr, 2001).

Table 2. Prominence of agricultural training advertisements in selected Nigerian newspapers

\begin{tabular}{|c|c|c|c|c|c|c|c|c|}
\hline Position of Advertisement & \multicolumn{2}{|c|}{$\begin{array}{l}\text { Daily } \\
\text { Times }\end{array}$} & \multicolumn{2}{|c|}{$\begin{array}{c}\text { The } \\
\text { Guardian }\end{array}$} & \multicolumn{2}{|c|}{$\begin{array}{l}\text { Nigerian } \\
\text { Tribune }\end{array}$} & \multicolumn{2}{|c|}{ Overall } \\
\hline Agricultural Advertisement & Freq. & $\%$ & Freq. & $\%$ & Freq. & $\%$ & Freq. & $\%$ \\
\hline Front Page & 2 & 2.4 & 0 & 0.0 & 4 & 3.8 & 6 & 3.0 \\
\hline Back Page & 7 & 8.5 & 1 & 7.1 & 10 & 9.5 & 18 & 9.0 \\
\hline Centre Page & 2 & 2.4 & 0 & 0.0 & 3 & 2.9 & 5 & 2.5 \\
\hline Special Page & 4 & 4.9 & 1 & 7.1 & 4 & 3.8 & 9 & 4.5 \\
\hline Other Page & 67 & 81.7 & 12 & 85.7 & 84 & 80.0 & 163 & 81.1 \\
\hline Total & 82 & 100 & 14 & 100 & 105 & 100 & 201 & 100 \\
\hline Position of Advertisements & \multicolumn{2}{|c|}{$\begin{array}{l}\text { Daily } \\
\text { Times }\end{array}$} & \multicolumn{2}{|c|}{$\begin{array}{c}\text { The } \\
\text { Guardian }\end{array}$} & \multicolumn{2}{|c|}{$\begin{array}{l}\text { Nigerian } \\
\text { Tribune }\end{array}$} & \multicolumn{2}{|c|}{ Overall } \\
\hline Non-agricultural Advertisements & Freq. & $\%$ & Freq. & $\%$ & Freq. & $\%$ & Freq. & $\%$ \\
\hline Front Page & 19 & 12.3 & 24 & 23.8 & 34 & 22.2 & 77 & 18.9 \\
\hline Back Page & 39 & 25.3 & 48 & 47.5 & 36 & 23.5 & 123 & 30.1 \\
\hline Centre Page & 20 & 13.0 & 5 & 5.0 & 44 & 28.8 & 69 & 16.9 \\
\hline Special Page & 21 & 13.6 & 3 & 3.0 & 16 & 10.5 & 40 & 9.8 \\
\hline Other Pages & 55 & 35.7 & 21 & 20.7 & 23 & 15.0 & 99 & 24.3 \\
\hline Total & 154 & 100 & 101 & 100 & 153 & 100 & 408 & 100 \\
\hline
\end{tabular}


Table 3 presents the result of chi square analysis which shows that there is significant association between the placements of agricultural training advertisements and type of newspapers $\left(\chi^{2}=\right.$ 60.53, p<0.05). This implies that advertisement placement on prominent pages of newspapers is determined by the policy of print media organization which also varies with cost of advertisement. The Cramer's V test of strength of association shows that the association between the categories of advertisements and the focal newspapers is strong (Cramer's $\mathrm{V}=0.19$, $\mathrm{p}<0.05)$.

Table 3. Chi square analysis of relationship between categories of agricultural training advertisements in the focal newspapers $(n=201)$

\begin{tabular}{lcccccc}
\hline Variables & Tool & $\mathrm{df}$ & value & $\mathrm{p}$ & Cramer V & Decision \\
\hline $\begin{array}{l}\text { Categories of Advertisements } \\
* \text { Newspapers }\end{array}$ & $\chi^{2}$ & 12 & 45.11 & 0.00 & 0.19 & Significant \\
\hline
\end{tabular}

Significant at $\mathrm{p}<0.05$

\section{Conclusion and Recommendations}

The study concluded that the advertisements of agricultural training placed in Nigerian newspapers were not given adequate coverage and prominence. The study has revealed that while the coverage of agricultural items in the papers is all-inclusive, such news items are not given positions of prominence in the newspapers. This is a serious cause for concern when viewed against the need to provide exposure to new entrants literate farmers in the agricultural sector. Indeed, agriculture should be accorded its dominance role in the Nigerian economy as it was before the discovery of crude oil, which is now the main stay of the economy. It is therefore recommended that agricultural news items should be given more prominence and sponsors of agricultural programmes should be encouraged to help in reducing the cost of advertisement as agricultural training advertisements can be a panacea for increased information source to new entrants, especially the urban farmers on agricultural training programmes.

\section{References}

Agumagu, A.C. 1988. Agricultural reporting in Nigerian news paper: The case of Daily Times and the New Nigeria, 1985-1986. Nigerian Agril. J. 23 (2): 71-80.

FAO. 1997. Issues and Opportunities for Agricultural Education and Training in the 1990s and beyond. Rome. pp. 49-50.

Fawole, P.O. 1995. Coverage of Women's Agricultural activities in Nigerian Daily Newspapers. $\mathrm{PhD}$ Thesis. Department of Agricultural Extension Services, University of Ibadan, Ibadan, Nigeria. 217 p.
Media World. 1996. Newspapers and Magazines list in Nigeria. http:// newslink.org.

Oladeji, J.O. 1999. Content analysis of Visuals and Information Cues of Agricultural Advertisements in Nigerian Daily Newspapers. $\mathrm{PhD}$ Thesis. Department of Agricultural Extension Services, University of Ibadan, Nigeria. $213 \mathrm{p}$.

Oladeji, J.O. and Fawole, O.P. 1999. Content Analysis. pp. 23-29. Oladele. O.I., Akinbile, L.A. and Adekoya, A.E. (eds). In: SocialScience Research: Approaches, Techniques, and Reporting. Ijebu-Ode: Shanu Books Nigeria Limited.

Oladeji, J.O. and Olowu, T.A. 2001 Agricultural Advertisements in Nigerian Newspapers - A Content Analysis. J. Soc. \& Agril. Res. 1 (1): 34-37.

Oloruntoba, A. and Olowu, T.A. 2001. Content Analysis of Training Programme Advertisements in The Guardian Newspaper. Nigerian J. Agril. Dev. Stud. 2 (1): 90-96.

Olowu, T.A. 1990. Reportage of Agricultural News in Nigerian Newspapers. J ournalism Quart. 67 (1): 195-200.

Reilly, W. and Clark, R. 1990. Training for Public Management. A Handbook for Management Development; Human Resources Development Group, London. pp. 23-25.

Salawu, S. 1983. The Nigerian press and the neglect of the rural majority. A paper presented at the Inaugural Conference of the Nigerian Mass- Communication Association, Lagos. p. 7. 